\title{
The Internal Market as a Legal Concept \\ Stephen Weatherill
}

Reviewed by Ana Teresa Ribeiro*

\section{Introduction}

The internal market is an essential foundation of the EU. However, and despite this evidence, it is surrounded by numerous uncertainties regarding its contents, reach, and limits. This is the premise of The internal market as a legal concept, by Stephen Weatherill, in which the Author offers an approach to the internal market as an ambiguous legal concept.

With this as a starting point, the intent behind the book is to provide an analysis of all the elements imbedded in this notion, as well as an insight into the distribution of powers regarding its regulation. These questions concern both the vertical (between the EU and its Member States) and the horizontal (between the Court and the legislative institutions of the EU) allocation of competences.

In order to achieve this goal, the Author resorts to an extensive examination of the EU's case law, but also of the legislative measures adopted in this context. Furthermore, the way in which this matter is handled is highly pedagogical, with a clear and comprehensive method of exposition.

\section{Book chapters}

The book is divided into 16 chapters. In the first one, named after this volume, the Author explains that, although legally defined as "an area without internal frontiers in which the free movement of goods, persons, services and capital is ensured in accordance to the provisions of the Treaties",

\footnotetext{
* Lecturer at the Oporto Law School of Universidade Católica Portuguesa, 4169-005 Porto, Portugal. Grantee of Fundação para a Ciência e a Tecnologia (FCT), PhD scholarship programme (SFRH/BD/121318/2016), under the European Social Fund (Fundo Social Europeu - FSE) and with funding from POCH (Programa Operacional Capital Humano). aribeiro@porto.ucp.pt.

${ }^{1}$ See Article 26 TFEU.
} 
the internal market is still a rather ambiguous concept. ${ }^{2}$ In fact, and as previously stated, many essential aspects of its regime are left completely unanswered.

The second chapter, "Finding the internal market in the Treaty", addresses the issue of distribution of competences on this matter, scanning the outline of EU's powers concerning both positive and negative action, in light of the principle of conferral.

Further along in "The law, politics and economics of the internal market", the book offers a historic excursion into the internal market in order to assess its place and importance. It shows the relation between this concept and the (erased by the Lisbon Treaty) common market. From this analysis we can gather that, although there is an obvious economic component, the internal market also targets other areas. The Court stated as much in the case Defrenne v. SABENA, where it recognised that the EU also aims to ensure social progress and the constant improvement of the living and working conditions of its peoples.

The fourth topic, "Principal themes and structure", highlights the internal market as a continuous exercise (as stated by the European Commission). In order to provide for its construction, the Treaties prescribe two sets of regulations. While some prevent public and private actors from impeding cross-border trade, others grant competence to the EU to adopt its own common rules, in order to determine the terms of that said cross-border trade. In this respect, the book questions which national practices should be deemed incompatible with the internal market and which can, nonetheless, be considered a justified breach. Furthermore, it also addresses the constitutional balance of powers between the Court and the legislative institutions. Naturally, the answer to these queries depends on the notion of internal market.

Consequently, the next chapter is dedicated to this task, more particularly to the ascertaining of the "market" component. Here we realise the broadness of this concept, since, in principle, it encompasses all sectors of the economy, making it necessary to determine the (few) situations in which it is not applicable.

To this purpose, the Court of Justice of the EU ("the Court") plays a key role and it rarely has any problem "finding" a market. The notion of goods

\footnotetext{
${ }^{2}$ Sharing the same view, see Jukka Snell, "The Internal Market and the Philosophies of Market Integration", in European Union Law, ed. Catherine Barnard and Steven Peers (Oxford: Oxford University Press, 2014), 300.
} 
is vast, covering from bees to waste, and even lottery is considered an economic activity within the meaning of the Treaty. In fact, in competition law, the concept of undertaking covers any entity engaged in an economic activity, regardless of its legal status and financing conditions. This means that any activity consisting in offering goods or services on a given market is an economic activity (although those that are associated with the exercise of public powers, as well as collective bargaining, are excluded from the rules of competition).

The notion of worker is also quite broad (it has a specific meaning to EU law and, given its role of defining the scope of a fundamental freedom, it must be a wide concept). However, it does not encompass self-employed workers, who are considered as individual undertakings for this effect (and the same goes for their unions, which, in this context, will not be considered as social partners).

It has also been determined that Article 56 TFEU covers not only the freedom to provide services in another Member State, but also to receive services, comprising the freedom for recipients of a service to go to another Member State in order to receive it there. There is also no need for a direct payment, as long as remuneration is somehow provided. However, although this provision covers health services, it does not apply to secondary and higher education, where it is funded essentially out of the public purse (therefore it comprises private education). Finally, it should also be stressed that free movement and competition provisions are not confined to the areas in which the EU enjoys legislative competence, as was demonstrated by cases such as Viking Line and Laval. As the Author concludes, the "market" is such a broad concept that it empowers, more that limits, the Union.

Moving further, chapter six devotes itself to the "internal" aspect of the market, clarifying that EU provisions do not apply where all the case elements are internal to one Member State. In its early (easier) rulings, the Court had little difficulty in finding a cross-border dimension. However, as time went by, the criteria became more stretched (particularly since the cross-border element could be merely potential). This was amplified by cases brought on by applicants who were ingeniously trying to expand this jurisprudence, which led to some missteps on the Court's behalf (as shown by the Sunday trading cases and also some rulings relating to EU citizenship) and to the need to readjust its line of decision.

In turn, chapter seven targets the "personal scope" of provisions related to the internal market, since the Treaties do not clarify this issue. According 
to the Court, while free movement provisions apply to the acts of public authorities from the Member States, stipulations on the free movement of workers and services apply directly to private parties (but the same does not apply to the free movement of goods, as stated in Schmidberger v. Austria).

The following topic, "Justification", deals with the need to justify national actions when these create barriers to inter-state trade. In fact, as long as they rely on grounds of public morality, public policy or public security; the protection of health and life of humans, animals or plants; the protection of national treasures possessing artistic, historic or archaeological value; or the protection of industrial and commercial property, ${ }^{3}$ they will be considered valid - as long as they do not constitute a means of arbitrary discrimination or a disguised restriction on trade between Member States. Articles 45, 52, and 62 TFEU provide justifications along the same lines regarding freedom of persons, of establishment and of services. Whereas national measures are deemed necessary to provide these goals, they will be compatible with EU law. Naturally, there is extensive case law dissecting these provisions, showing, furthermore, that the scope of justification is not confined to the topics explicitly mentioned therein.

Chapter nine, "Creativity in the gap between negative and positive law. The principle of conferral unleashed", shows how the Court has gone beyond situations strictly comprised in the EU's competence in order to assess whether national measures respect inter-state trade. The Bosman case is a clear example of this situation, as well the Laval and Viking Line decisions. These last two judgements are heavily and rightfully criticised, not only because the Court significantly favoured corporate interests over worker protection, but also because it denied any margin of appreciation of local circumstances, unlike its previous line of reasoning. ${ }^{4}$

However, in my opinion, the book should also have stressed the challenges that these decisions may pose to Member States, when their contents collide with legal obligations arising from other jurisdictions. This was particularly acute in the Laval case. Sweden amended its legislation to comply with the Court's ruling and was then considered to be in violation

\footnotetext{
${ }^{3}$ See Article 36 TFEU.

${ }^{4}$ See Jonas Malmberg and Tore Sigeman, "Industrial Actions and EU Economic Freedoms: The Autonomous Collective Bargaining Model Curtailed by the European Court of Justice", Common Market Law Review 45, 4 (2008): 1130.
} 
of the European Social Charter. ${ }^{5}$ Therefore, it would have been interesting to underline the difficulties that Member States face while endeavouring to articulate diverging commitments on the same matter.

In the following chapter, "Abuse", the Author addresses situations in which the invocation of EU provisions was seen as distorting their intentions and the way the Court decided to deal with these cases.

In "Fundamental rights and national identity in the internal market", it is stressed that both the positive and negative aspects of the internal market must comply with the fundamental rights. The Author enumerates several decisions which had to do with this matter, illustrating the balance that was stroke between national constitutional values and the needs of the internal market.

Chapter twelve deals with "The internal market as a site of diversity", emphasising how this is a space with not only several different products and services, but also disparate national rules. This circumstance conferred particular relevance to the Court's role. In fact, it became in charge not only of determining the national margin of appreciation, but also of achieving a significant harmonisation that would otherwise have to be pursued through extensive legal regulation. ${ }^{6}$

Afterwards, in "The legislative dimension. Harmonization" we are introduced to the notion that, despite its importance, deregulation is not everything. As it is, the internal market also relies on the role played by EU's legislation. This entails the adoption of common rules at EU level, with the aim of levelling the regulatory field and promoting a common trading area. Naturally, this may affect national practices that function as a justified barrier to inter-state trade. In fact, while jurisprudence deregulates this matter (attacking unjustified national barriers to inter-state trade), legislation re-regulates it (forcing the change of justified obstructions). Nevertheless, and as stated before, EU's legislative competence in this matter, although quite broad, is not unlimited.

In turn, in "Legislative competence more broadly", the book explores the Treaties' provisions that allow for this legislative intervention on the

\footnotetext{
${ }^{5}$ See Decision on admissibility and the merits, Swedish Trade Union Confederation (LO) and Swedish Confederation of Professional Employees (TCO) v. Sweden, Complaint no. 85/2012. http:// hudoc.esc.coe.int/eng?i=cc-85-2012-dadmissandmerits-en). See also, regarding this particular matter, Carmen Salcedo Beltrán, Negociación Colectiva, Conflito Laboral y Carta Social Europeia (Albacete: Editorial Bomarzo, 2014).

${ }^{6}$ With such success that the EU's internal market is more integrated than some national markets (v.g. the Canadian).
} 
internal market, either explicitly or by implication, as well as jurisprudence relating to this issue (related to social policy and labour market).

The following chapter, entitled "Pre-emption", deals with the legislative competence that is still allowed to each Member State. The decision on this matter depends on the kind of desired harmonisation (maximum or minimum), and the Author explains both the advantages and difficulties of each model.

Finally, the book concludes with a return to the initial idea: while aiming at the construction of an internal market, the Treaties have surrounded this concept with a number of questions, such as the precise vertical distribution of competences between the EU and the Member States, and the horizontal distribution of powers between the EU's political institutions and the Court. And, due to this ambiguity, the latter has been able to provide for a significant interpretative contribution. The bottom line of the discussion is that the internal market is a permanently evolving concept, never to be finalised.

\section{Conclusion}

The internal market is one of the building concepts of EU law and yet it lacks a precise outline. It raises questions not only regarding its reach, contents, and limitations, but also concerning the distribution of powers regarding its regulation.

Therefore, The internal market as a legal concept makes a very valuable contribution by shedding light on these matters, while explaining them in a most clear and illustrative way.

\section{Bibliography}

Malmberg, Jonas, and Sigeman, Tore. "Industrial Actions and EU Economic Freedoms: The Autonomous Collective Bargaining Model Curtailed by the European Court of Justice”. Common Market Law Review 45, 4 (2008): 1115-1146.

Salcedo Beltrán, Carmen. Negociación Colectiva, Conflito Laboral y Carta Social Europeia. Albacete: Editorial Bomarzo, 2014.

Snell, Jukka. "The Internal Market and the Philosophies of Market Integration”. In European Union Law, edited by Catherine Barnard and Steven Peers, 300-324. Oxford: Oxford University Press, 2014. 